\title{
Heterologous expression, biochemical characterization, and overproduction of alkaline $\alpha$-amylase from Bacillus alcalophilus in Bacillus subtilis
}

Haiquan Yang ${ }^{1,2}$, Long Liu ${ }^{1,2^{*}}$, Jianghua $\mathrm{Li}^{1,2}$, Guocheng $\mathrm{Du}^{1}$ and Jian Chen ${ }^{1,3^{*}}$

\begin{abstract}
Background: Alkaline $\alpha$-amylases have potential applications for hydrolyzing starch under high $\mathrm{pH}$ conditions in the starch and textile industries and as ingredients in detergents for automatic dishwashers and laundries. While the alkaline $\alpha$-amylase gains increased industrial interest, the yield of alkaline $\alpha$-amylases from wild-type microbes is low, and the combination of genetic engineering and process optimization is necessary to achieve the overproduction of alkaline $\alpha$-amylase.

Results: The alkaline $\alpha$-amylase gene from Bacillus alcalophilus JN21 (CCTCC NO. M 2011229) was cloned and expressed in Bacillus subtilis strain WB600 with vector pMA5. The recombinant alkaline $\alpha$-amylase was stable at pH from 7.0 to 11.0 and temperature below $40^{\circ} \mathrm{C}$. The optimum $\mathrm{pH}$ and temperature of alkaline $\alpha$-amylase was 9.0 and $50^{\circ} \mathrm{C}$, respectively. Using soluble starch as the substrate, the $K_{m}$ and $V_{\max }$ of alkaline $\alpha$-amylase were $9.64 \mathrm{~g} / \mathrm{L}$ and $0.80 \mathrm{~g} /(\mathrm{L} \cdot \mathrm{min})$, respectively. The effects of medium compositions (starch, peptone, and soybean meal) and temperature on the recombinant production of alkaline $\alpha$-amylase in $B$. subtilis were investigated. Under the optimal conditions (starch concentration $0.6 \%(\mathrm{w} / \mathrm{v})$, peptone concentration $1.45 \%(\mathrm{w} / \mathrm{v})$, soybean meal concentration $1.3 \%(\mathrm{~W} / \mathrm{v})$, and temperature $\left.37^{\circ} \mathrm{C}\right)$, the highest yield of alkaline $\alpha$-amylase reached $415 \mathrm{U} / \mathrm{mL}$. The yield of alkaline $\alpha$-amylase in a 3-L fermentor reached $441 \mathrm{U} / \mathrm{mL}$, which was 79 times that of native alkaline $\alpha$ amylase from B. alcalophilus JN21.
\end{abstract}

Conclusions: This is the first report concerning the heterologous expression of alkaline $\alpha$-amylase in $B$. subtilis, and the obtained results make it feasible to achieve the industrial production of alkaline $\alpha$-amylase with the recombinant $B$. subtilis.

\section{Background}

$\alpha$-Amylases (1, 4- $\alpha$-D-glucan glucanohydrolase; EC 3.2.1.1) are endo-acting enzymes that hydrolyze starch by cleaving $\alpha-1$, 4-glucosidic linkages [1], and have been widely used in food, textile, and pharmaceutical industries [2-7]. The alkaline $\alpha$-amylases have high catalytic efficiency and stability at the alkaline $\mathrm{pH}$ ranging from 9 to 11 [8-11], and have potential applications for hydrolyzing starch under high $\mathrm{pH}$ conditions in the starch

\footnotetext{
* Correspondence: longliu@jiangnan.edu.cn; jchen@jiangnan.edu.cn ${ }^{1}$ Key Laboratory of Industrial Biotechnology, Ministry of Education, Jiangnan University, Wuxi 214122, China

Full list of author information is available at the end of the article
}

and textile industries and as ingredients in detergents for automatic dishwashers and laundries [3-8].

While the alkaline $\alpha$-amylases have potential applications in textile and detergent industries, relatively few efforts have been made to improve the yield of alkaline $\alpha$-amylases. The current studies mainly focus on the strain screening, enzyme purification, and properties characterization [3,9,12-19].

The yield of alkaline $\alpha$-amylase from wild-type microbes, especially from extremophilic microbes, is usually low and hard to be improved, even with process optimization and control $[13,14,16]$. It is necessary to use genetic engineering to clone and express the alkaline amylase gene in a suitable host for the further

\section{() Biomed Central}


improvement of enzyme yield. The alkaline $\alpha$-amylase from Bacillus halodurans MS-2-5 and Bacillus halodurans 38C-2-1 was expressed in Escherichia coli and the highest yield reached $52 \mathrm{U} / \mathrm{mL}$ under the optimal conditions [3,7]. Compared with E. coli, Bacillus subtilis is non-pathogenic and bacteriophage-resistant, and has been extensively used for the overproduction of heterologous proteins [20-28]. Nevertheless, the cloning and expression of alkaline $\alpha$-amylase gene in $B$. subtilis have not been reported.

In our previous work, a strain capable of producing alkaline $\alpha$-amylase was isolated and identified as Bacillus alcalophilus JN21 (CCTCC NO. M 2011229), and the optimum $\mathrm{pH}$ and temperature of the alkaline $\alpha$-amylase were 9.5 and $55^{\circ} \mathrm{C}$, respectively [29]. In this work, B. subtilis expression system was constructed to clone and express the alkaline $\alpha$-amylase from B. alcalophilus JN21. The biochemical characterization of the recombinant alkaline $\alpha$ amylase was also performed. To achieve the over-production of alkaline $\alpha$-amylase in B. subtilis, the key media components (starch, peptone, and soybean meal) and temperature were optimized in shaker flask. The production of alkaline $\alpha$-amylase by $B$. subtilis was conducted in a 3-L fermentor under the obtained optimal conditions. The results obtained here may be useful for the achievement of industrial alkaline $\alpha$-amylase production.

\section{Results and Discussion}

\section{Expression of recombinant alkaline $\alpha$-amylase in $B$. subtilis}

DNA fragment coding for mature alkaline $\alpha$-amylase was obtained from B. alcalophilus JN21 by PCR and cloned into the B. subtilis expression vector, pMA5 (Figure 1(a)). Nucleotide sequence analysis showed that the gene length was $1671 \mathrm{bp}$ and the encoded protein consisted of 557 amino acids. The target fragment was integrated into B. subtilis WB600 strain. The transformants were selected at $37^{\circ} \mathrm{C}$ on the LB agar plates containing $100 \mu \mathrm{g} /$ $\mathrm{mL}$ Kanamycin and $1 \%$ soluble starch. The transformants with transparent rings around colonies were positive. The insertion of alkaline $\alpha$-amylase gene in the transformants was confirmed by PCR. The B. subtilis WB600 transformed with vector pMA5 was used as the control. The colonies were grown in $25 \mathrm{~mL}$ of LB medium at $37^{\circ}$ $\mathrm{C}$ for $36 \mathrm{~h}$ in $250 \mathrm{~mL}$ shaker flasks. The alkaline $\alpha$-amylase activity in the culture supernatant was $99 \mathrm{U} / \mathrm{mL}$. The alkaline $\alpha$-amylase activity in the culture supernatant of control strain was determined under the same culture conditions and the activity was $4 \mathrm{U} / \mathrm{mL}$. The yield of recombinant alkaline $\alpha$-amylase in the culture media of engineered $B$. subtilis was 18 times that of native alkaline $\alpha$-amylase from B. alcalophilus JN21.

SDS-PAGE analysis showed that there was one major band of protein (approximate $56 \mathrm{kDa}$ ) secreted into the culture medium (Figure 1(b)). The recombinant alkaline $\alpha$-amylase was purified from culture supernatant by the anion exchange (Q-Sepharose HP), and the specific activity of purified enzyme was $168 \mathrm{U} / \mathrm{mg}$.

Effect of $\mathrm{pH}$ and temperature on the activity and stability of alkaline $\alpha$-amylase

Effect of $\mathrm{pH}$ on the activity and stability of recombinant alkaline $\alpha$-amylase was determined. As shown in Figure 2(a), the optimum $\mathrm{pH}$ of recombinant alkaline

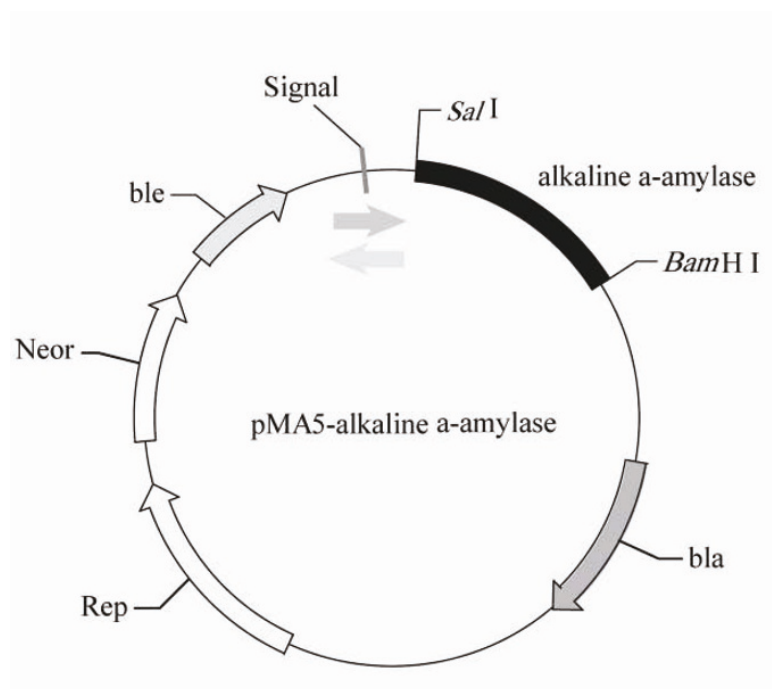

a

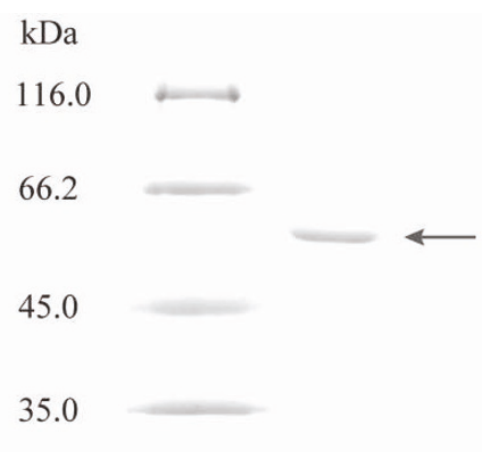

25.0

18.4

Figure 1 Map of expression vector and SDS-PAGE analysis. a: Map of expression vector pMA5-alkaline $\alpha$-amylase. b: SDS-PAGE analysis of purified alkaline $\alpha$-amylase. Fragment indicated by arrow: alkaline $\alpha$-amylase. 
$\alpha$-amylase was around 9.8. The activity of alkaline $\alpha$ amylase increased with the increase of $\mathrm{pH}$ from 7.0 to 9.8, and exhibited the highest value (> 90\% of maximum) between $\mathrm{pH} 9.0$ and 10.0. The activity of alkaline $\alpha$-amylase rapidly declined when $\mathrm{pH}$ was lower than 7.0 or higher than 10.0 .

Figure 2(b) shows that the recombinant alkaline $\alpha$ amylase was very stable, retaining more than $85 \%$ of its maximal activity between $\mathrm{pH} 8.0$ and 11.0 after incubation at $25^{\circ} \mathrm{C}$ for $24 \mathrm{~h}$, and displayed optimal stability at around $\mathrm{pH}$ 8.6. Less than $20 \%$ of its maximal activity was retained when $\mathrm{pH}$ was lower than 7.0 or higher than 11.0, and the activity was completely lost when the $\mathrm{pH}$ was at 4.0 or 13.0 .

Figure 3(a) shows that the recombinant alkaline $\alpha$ amylase activity increased with temperature increasing from 30 to $50^{\circ} \mathrm{C}$ and decreased with temperature increasing from 50 to $70^{\circ} \mathrm{C}$. The optimum temperature was $50^{\circ} \mathrm{C}$, at which the activity of alkaline $\alpha$-amylase was 4.6 times that at $70^{\circ} \mathrm{C}$. The alkaline $\alpha$-amylase retained approximately $60 \%$ of activity after incubation at $30^{\circ} \mathrm{C}$ at $\mathrm{pH} 9.0$ for $12 \mathrm{~h}$ or at $40^{\circ} \mathrm{C}$ at $\mathrm{pH} 9.0$ for $2 \mathrm{~h}$, but was rapidly inactivated above $50^{\circ} \mathrm{C}$ (Figure $3(\mathrm{~b})$ ). The half time of alkaline $\alpha$-amylase was more than $12 \mathrm{~h}$ at $30^{\circ} \mathrm{C}$, whereas decreased to 2 and $1.5 \mathrm{~h}$ when at 40 and $50^{\circ} \mathrm{C}$, respectively.

The kinetic parameters of recombinant alkaline $\alpha$-amylase The kinetics of the recombinant alkaline $\alpha$-amylase was analyzed using soluble starch as substrate. The $K_{\mathrm{m}}$ and $V_{\max }$ valves were determined by nonlinear fit analysis based on Eadie-Hofstee plots [30]. The initial reaction rates were determined with soluble starch as the substrate with the concentration ranging from 1.0 to $10.0 \mathrm{~g} / \mathrm{L}$. The recombinant alkaline $\alpha$-amylase hydrolyzed soluble starch with Michaelis constant $\left(K_{\mathrm{m}}\right)$ of $9.64 \mathrm{~g} / \mathrm{L}$ and maximum reaction rate $\left(V_{\max }\right)$ of $0.80 \mathrm{~g} /$ $(\mathrm{L} \cdot \mathrm{min})$ at $55^{\circ} \mathrm{C}$ (Figure 4$)$. The turnover number $\left(k_{\text {cat }}\right)$ and the catalytic efficiency $\left(k_{\mathrm{cat}} / K_{\mathrm{m}}\right)$ of the alkaline $\alpha$ amylase were $7.53 \mathrm{~min}^{-1}$ and $0.78 \mathrm{~L} /(\mathrm{g} \cdot \mathrm{min})$, respectively.

\section{Effect of metal ions on the stability of alkaline $\alpha$-amylase}

Metal ions played a key role in protein folding and catalysis [31]. As shown in Table 1, the purified recombinant alkaline $\alpha$-amylase was activated by $1 \mathrm{mM} \mathrm{Na}^{+}$, indicating that the alkaline $\alpha$-amylase activity was $\mathrm{Na}^{+}$-dependent with a relative activity of $110 \%$. The $\mathrm{Ca}^{2+}(1 \mathrm{mM})$ and $\mathrm{K}^{+}$ $(10 \mathrm{mM})$ almost had no activation or inhibition on the alkaline $\alpha$-amylase with a relative activity of $102 \%$ and $100 \%$, respectively. The following metal ions had slight inhibitions on enzyme activity: $\mathrm{Na}^{+}(10 \mathrm{mM}), \mathrm{Ca}^{2+}(10$ $\mathrm{mM}), \mathrm{Co}^{2+}$ (1 and $\left.10 \mathrm{mM}\right), \mathrm{Zn}^{2+}(1$ and $10 \mathrm{mM}), \mathrm{Mg}^{2+}(1$ and $10 \mathrm{mM}), \mathrm{Cu}^{2+}(1$ and $10 \mathrm{mM}), \mathrm{Fe}^{3+}(1$ and $10 \mathrm{mM}), \mathrm{K}$ ${ }^{+}(1 \mathrm{mM})$ and $\mathrm{Fe}^{2+}(10 \mathrm{mM})$. On the other hand, the stronger inhibitory effects were observed in the presence of $\mathrm{Fe}^{2+}(1 \mathrm{mM})$ and $\mathrm{Mn}^{2+}$ (1 and $\left.10 \mathrm{mM}\right)$, and only $26.5 \%$ of activity was retained in the presence of $10 \mathrm{mM} \mathrm{Mn}^{2+}$. The inhibitions of divalent metal ions on $\alpha$-amylase from the other sources were also observed [32-35].

\section{Culture conditions optimization for the overproduction of alkaline $\alpha$-amylase by $B$. subtilis}

Figure 5(a) shows the influence of starch concentrations $(0,0.6,1.2,1.8,2.4,3.0,3.6$, and $4.2 \%(\mathrm{w} / \mathrm{v}))$ on the yield of recombinant alkaline $\alpha$-amylase. The yield of alkaline $\alpha$-amylase increased with the increase of starch
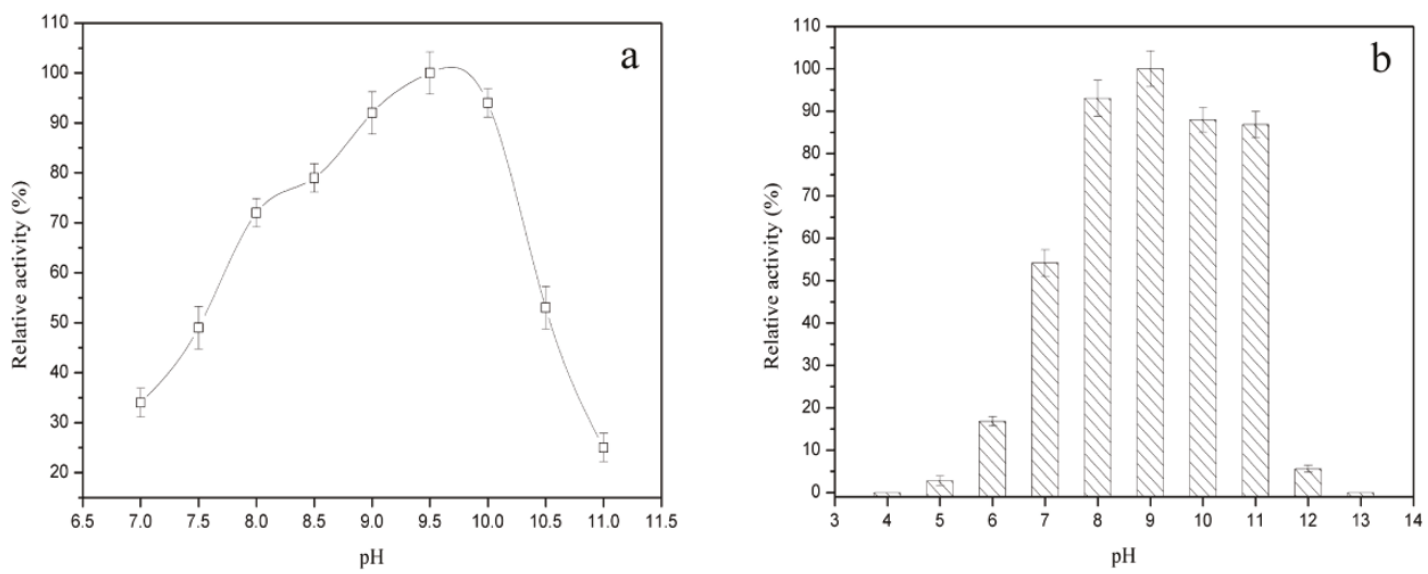

Figure 2 Effect of $\mathrm{pH}$ on the activity and stability of alkaline $\alpha$-amylase. a: Effect of $\mathrm{pH}$ on the activity of alkaline $\alpha$-amylase. The purified alkaline $\alpha$-amylase was incubated and determined in $0.1 \mathrm{M}$ glycine/ $\mathrm{NaOH}$ buffer $(\mathrm{pH} 7.0-11.0)$ at $55^{\circ} \mathrm{C}$. b: Effect of pH on the stability of alkaline $\alpha$-amylase. The $\mathrm{pH}$ stability of alkaline $\alpha$-amylase was determined at $\mathrm{pH}$ ranging from 4.0 to $13.0(0.1 \mathrm{M}$ glycine/ $/ \mathrm{HCl}$ buffer or glycine/ $\mathrm{NaOH}$ buffer) at $25^{\circ} \mathrm{C}$ for $24 \mathrm{~h}$. After incubation, the activity of alkaline $\alpha$-amylase was measured at $\mathrm{pH} 10.0$ and $55^{\circ} \mathrm{C}$. 

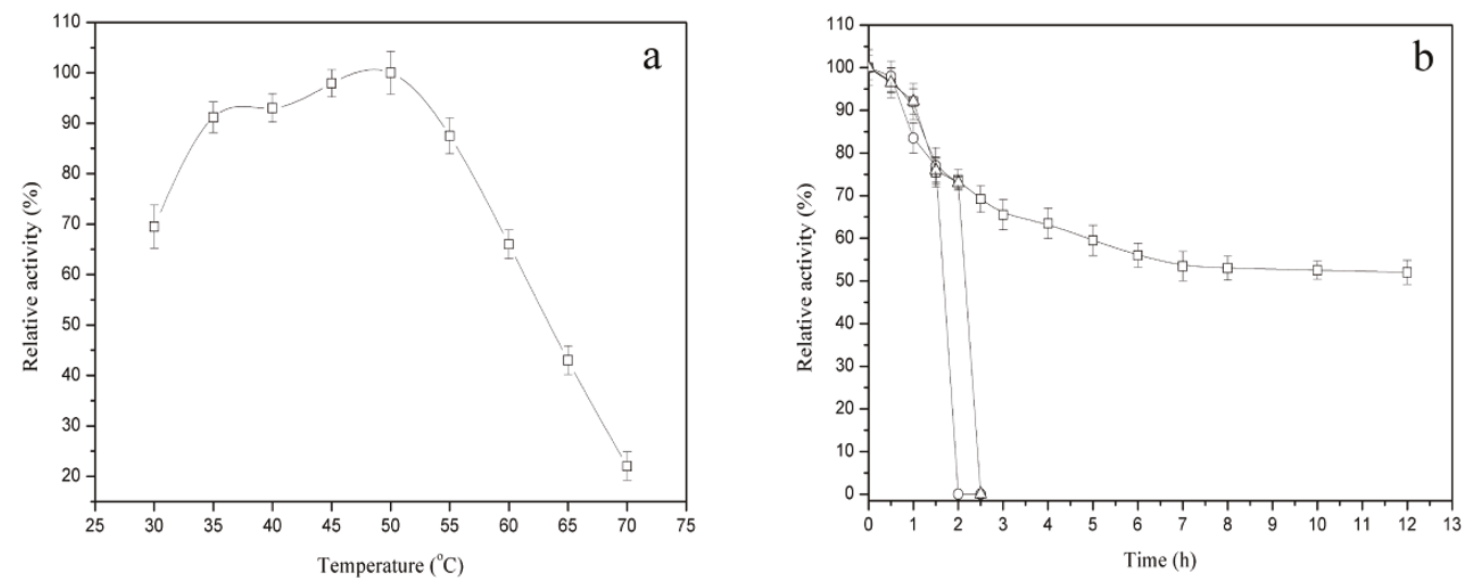

Figure 3 Effect of temperature on the activity and stability of alkaline $\alpha$-amylase. a: Effect of temperature on the activity of alkaline $\alpha$ amylase. To determine the optimal temperature of alkaline $\alpha$-amylase, the reaction was conducted from 30 to $70^{\circ} \mathrm{C}$ in glycine/ $\mathrm{NaOH}$ buffer $(\mathrm{pH}$ 10.0). b: Effect of temperature on the stability of alkaline $\alpha$-amylase. Square: $30^{\circ} \mathrm{C}$; Triangle: $40^{\circ} \mathrm{C}$; Circle: $50^{\circ} \mathrm{C}$. The thermal stability of alkaline $\alpha$ amylase was determined at the indicated temperatures in glycine/ $\mathrm{NaOH}$ buffer ( $\mathrm{pH} 10.0)$ for $12 \mathrm{~h}$. After incubation, the activity of alkaline $\alpha-$ amylase was measured at $\mathrm{pH} 10.0$ and $55^{\circ} \mathrm{C}$.

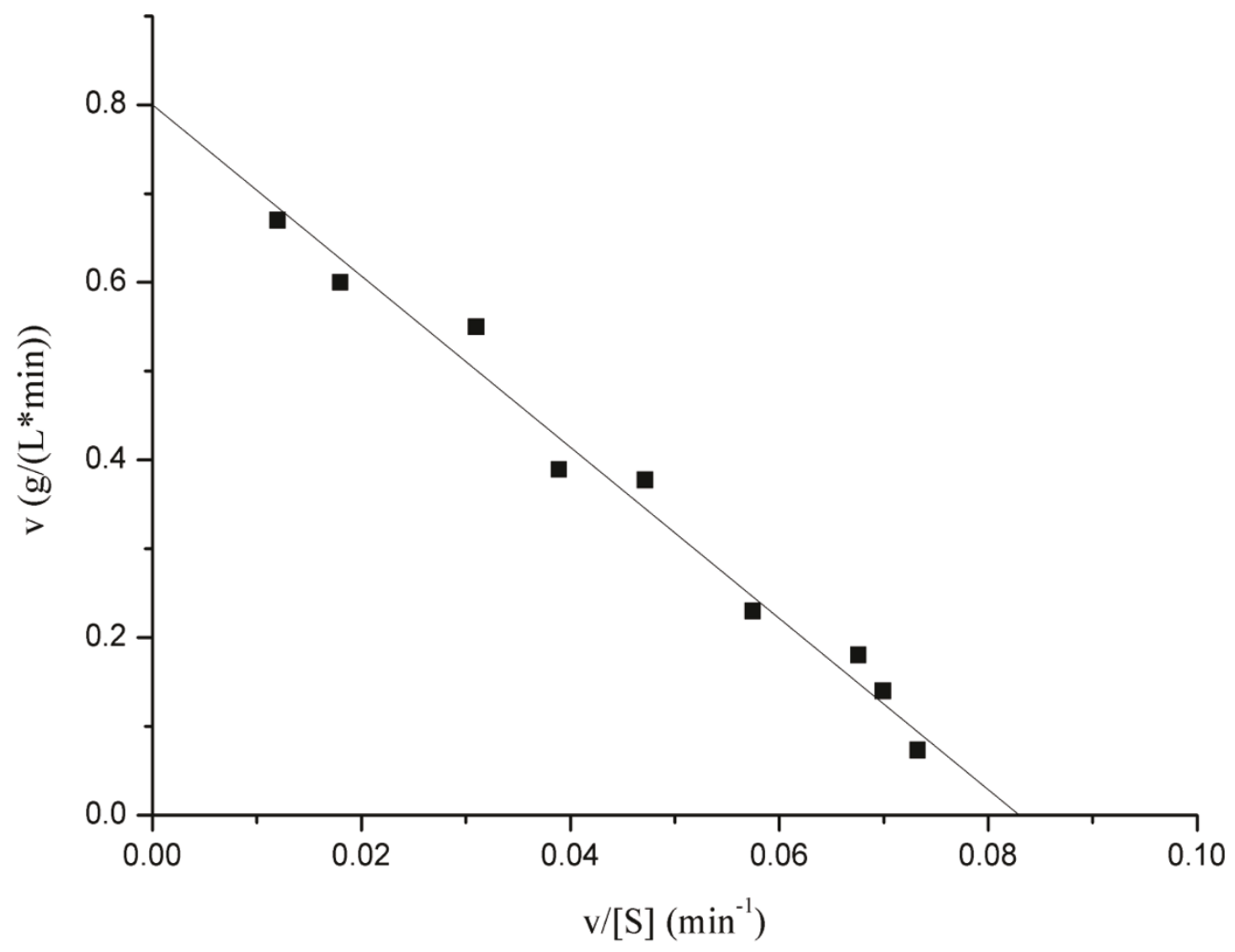

Figure 4 Eadie-Hofstee plots for soluble starch degradation by alkaline $\boldsymbol{\alpha}$-amylase. The soluble starch was used as the substrate with different concentrations ranging from 1 to $10 \mathrm{~g} / \mathrm{L}$. The determination of kinetic parameters was performed in glycine/ $\mathrm{NaOH}$ buffer ( $\mathrm{pH}$ 10.0) at $55^{\circ} \mathrm{C}$. 
Table 1 Effect of metal ions on the stability of alkaline $\alpha$ amylase

\begin{tabular}{lll}
\hline Metal ions & \multicolumn{2}{l}{ Relative activity (\%) } \\
\cline { 2 - 3 } & $\mathbf{1} \mathbf{~ m M}$ & $\mathbf{1 0} \mathbf{~ m M}$ \\
\hline $\mathrm{CK}^{\mathrm{a}}$ & 100 & 100 \\
$\mathrm{Na}^{+}$ & $110 \pm 2$ & $96 \pm 2$ \\
$\mathrm{Co}^{2+}$ & $97 \pm 2$ & $96 \pm 2$ \\
$\mathrm{Zn}^{2+}$ & $80 \pm 1$ & $85 \pm 1$ \\
$\mathrm{Ca}^{2+}$ & $102 \pm 2$ & $85 \pm 3$ \\
$\mathrm{~K}^{+}$ & $97 \pm 2$ & $100 \pm 2$ \\
$\mathrm{Mn}^{2+}$ & $37 \pm 1$ & $27 \pm 3$ \\
$\mathrm{Mg}^{2+}$ & $86 \pm 2$ & $84 \pm 2$ \\
$\mathrm{Fe}^{2+}$ & $74 \pm 2$ & $84 \pm 2$ \\
$\mathrm{Cu}^{2+}$ & $81 \pm 1$ & $88 \pm 1$ \\
$\mathrm{Fe}^{3+}$ & $90 \pm 2$ & $86 \pm 1$ \\
\hline
\end{tabular}

a The relative activity was calculated on the basis of the activity (CK) obtained in glycine/ $\mathrm{NaOH}$ buffer ( $\mathrm{pH} 10.0$ ) without the addition of any metal ions.

${ }^{b}$ Values represent means $\pm S D(n=3)$ relative to the untreated control samples.

concentration in a range from 0.0 to $0.6 \%$, and the maximal alkaline $\alpha$-amylase yield reached $311 \mathrm{U} / \mathrm{mL}$ at $0.6 \%$ starch. Alkaline $\alpha$-amylase yield decreased when more than $0.6 \%$ starch was added. The dry cell weight (DCW) increased with the increase of starch concentration up to $3.6 \%$.

As shown in Figure 5(b), the peptone of different concentrations $(0.45,0.95,1.45,1.95,2.45,2.95,3.45$, and $3.95 \%(\mathrm{w} / \mathrm{v}))$ was added into the medium. The addition of peptone within a suitable concentration range can greatly enhance the yield of alkaline $\alpha$-amylase, and the maximal alkaline $\alpha$-amylase production reached $360 \mathrm{U} /$ $\mathrm{mL}$ when $1.45 \%$ peptone was added. The cell density increased with the increase of peptone concentration. However, alkaline $\alpha$-amylase yield decreased when the peptone concentration was higher than $1.45 \%$.

The recombinant alkaline $\alpha$-amylase activity increased with the increase of soybean meal concentration, and reached the highest level of $412 \mathrm{U} / \mathrm{mL}$ at $1.3 \%$ soybean meal (Figure 5(c)). The further increase of soybean meal concentration higher than $1.3 \%$ was not favorable for alkaline $\alpha$-amylase production. The cell density increased with the increase of soybean meal concentration, and reached the highest level of $3.3 \mathrm{~g} / \mathrm{L}$ at $2.8 \%$ soybean meal.

As shown in Figure 5(d), the effects of temperature $\left(25,28,31,34,37\right.$, and $\left.40^{\circ} \mathrm{C}\right)$ on cell growth and alkaline $\alpha$-amylase production were investigated. The highest alkaline $\alpha$-amylase yield $(415 \mathrm{U} / \mathrm{mL})$ was observed at $37^{\circ} \mathrm{C}$, meanwhile the maximal cell density $(3.6 \mathrm{~g} / \mathrm{L})$ of $B$. subtilis also reached at $37^{\circ} \mathrm{C}$. The yield of recombinant alkaline $\alpha$-amylase significantly decreased at lower temperatures (below $37^{\circ} \mathrm{C}$ ) or higher temperatures (above $37^{\circ} \mathrm{C}$ ). The temperature was very important for the recombinant alkaline $\alpha$-amylase expression in B. subtilis.
Production of alkaline $\alpha$-amylase by recombinant $B$. subtilis in a 3-L fermentor

The expression efficiency of the engineered B. subtilis was further explored in a 3-L fermentor (BIOTRON, Korea). As shown in Figure 6, during the growth phase, the maximum cell concentrations in the fermentor reached $5.3 \mathrm{~g} / \mathrm{L}$. The expression of alkaline $\alpha$-amylase was continuously increased and reached the maximum yield of $441 \mathrm{U} / \mathrm{mL}$ at $36 \mathrm{~h}$. This yield was 79 times that of native alkaline $\alpha$-amylase extracted from Bacillus alcalophilus JN21 and 8.5 times that of alkaline $\alpha$-amylase from recombinant E. coli [7]. The high titer of alkaline $\alpha$-amylase indicated that $B$. subtilis was a suitable host for the industrial production of alkaline $\alpha$-amylase.

\section{Conclusions}

In this work, the gene of alkaline $\alpha$-amylase from $B$. alcalophilus JN21 was cloned and expressed in B. subtilis WB600. The optimum $\mathrm{pH}$ of recombinant alkaline $\alpha$ amylase was 9.5, and it displayed optimal stability at $\mathrm{pH}$ 9.0. The optimal temperature of the alkaline $\alpha$-amylase was $50^{\circ} \mathrm{C}$, and it was stable below $40^{\circ} \mathrm{C}$. The recombinant alkaline $\alpha$-amylase hydrolyzed soluble starch with $K_{\mathrm{m}}$ of $9.64 \mathrm{~g} / \mathrm{L}$ and $V_{\max }$ of $0.80 \mathrm{~g} /(\mathrm{L} \cdot \mathrm{min})$. The alkaline $\alpha$-amylase was slightly activated by $1 \mathrm{mM} \mathrm{Na}^{+}, 1 \mathrm{mM} \mathrm{Ca}^{2+}$ or $10 \mathrm{mM} \mathrm{K}^{+}$but inhibited by other metal ions. Under the optimal conditions (starch $0.6 \%$, peptone $1.45 \%$, soybean meal $1.3 \%$, and temperature $37^{\circ} \mathrm{C}$ ), the highest yield of alkaline $\alpha$-amylase reached $415 \mathrm{U} / \mathrm{mL}$, which was 4.2 fold that before optimization. The yield of alkaline $\alpha$ amylase in a 3-L fermentor reached $441 \mathrm{U} / \mathrm{mL}$.

\section{Materials and methods}

\section{Plasmids, bacterial strains and materials}

The strain of Bacillus alcalophilus JN21 (CCTCC NO: M 2011229) was an isolate of Lab of Bioprocess and Biosystems Engineering, Jiangnan University. Bacillus subtilis WB600, a strain that contains deletions of all six extracellular protease genes, and the plasmid pMA5 were obtained from Invitrogen. The EZ-10Spin Column Plasmid Mini-Preps kit, agarose gel DNA purification kit, restriction enzymes, and T4 DNA ligase were obtained from TakaRa (Dalian, China). Other chemicals were obtained from Shanghai Sangon Biological Engineering Technology \& Services Co. Ltd. (Shanghai, China). The synthesis of DNA primers and DNA sequencing were performed by Shanghai Sangon Biological Engineering Technology \& Services Co. Ltd. (Shanghai, China).

\section{Construction and transformation of the plasmid for secreted alkaline $\alpha$-amylase expression}

The E. coli/B. subtilis shuttle vector (pMA5) was used to clone and express alkaline $\alpha$-amylase. The mature alkaline $\alpha$-amylase gene was amplified by polymerase chain 

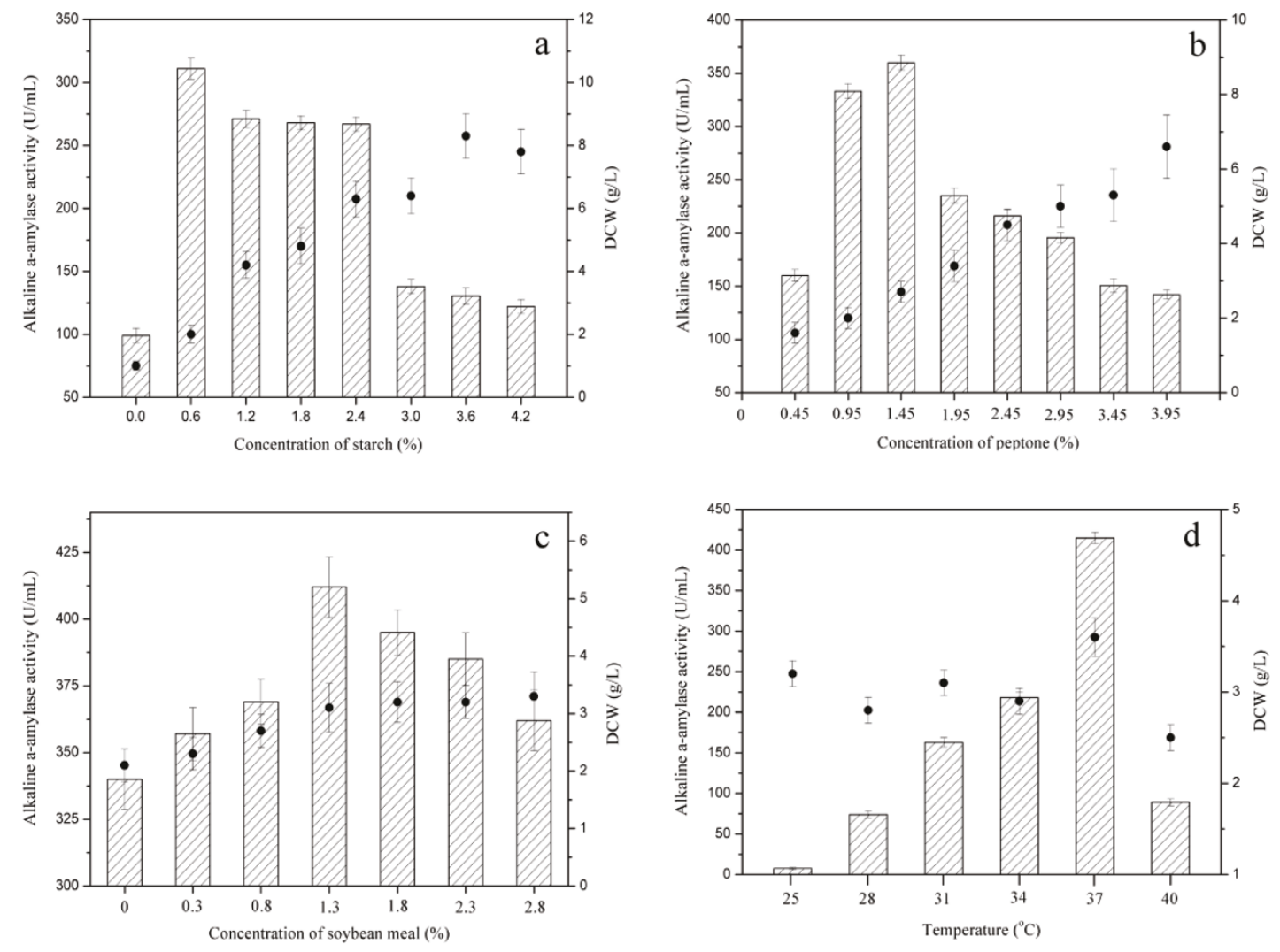

Figure 5 Optimization of medium constituents and process conditions for alkaline $\alpha$-amylase production by $B$. subtilis. Histogram: alkaline $\alpha$-amylase activity; Black dot: dry cell weight (DCW). a: Effect of starch on the recombinant $\alpha$-alkaline amylase production by $B$. subtilis. Different concentrations of starch added into the medium were $0,0.6,1.2,1.8,2.4,3.0,3.6$ and $4.2 \%(\mathrm{w} / \mathrm{v})$. b: Effect of peptone concentrations on the recombinant production of $\alpha$-alkaline amylase by $B$. subtilis. The different concentrations of peptone were $0.45,0.95,1.45,1.95,2.45,2.95,3.45$ and $3.95 \%(\mathrm{w} / \mathrm{v})$. c: Effect of soybean meal concentrations on the $\alpha$-alkaline amylase production by $B$. subtilis. The different concentrations of soybean meal were $0,0.3,0.8,1.3,1.8,2.3$ and $2.8 \%(w / v)$. d: Effect of temperature on the recombinant $\alpha$-alkaline amylase production by $B$. subtilis. The different temperatures were $25,28,31,34,37$ and $40^{\circ} \mathrm{C}$.

reaction (PCR) using gene-specific primers as follows: 5'ACGCGTCGACATGGAGCATASGGCCATGACGA3' (forward primer) and 5'CGGGATCCTTATGACCGCCGAATCAGTGAAGC3' (reverse primer). The forward primer and the reverse primer contained a $\mathrm{Sal}$ I and a BamH I restriction sites (underlined), respectively. The amplification was carried out under the following conditions: the first step was at $94^{\circ} \mathrm{C}$ for $10 \mathrm{~min}$, followed by 30 cycles of $95^{\circ} \mathrm{C}$ for $10 \mathrm{~s}, 60^{\circ} \mathrm{C}$ for $30 \mathrm{~s}$, and $72^{\circ} \mathrm{C}$ for 2 min, and the final extension was carried out at $72^{\circ} \mathrm{C}$ for $10 \mathrm{~min}$. The PCR product was digested with $\mathrm{Sal}$ I and BamH I, gel-purified and then ligated into pMA5 which was subjected to a similar treation. The recombinant plasmid was identified by restriction analysis and sequencing.

\section{Expression of alkaline $\alpha$-amylase in $B$. subtilis}

The recombinant plasmid pMA5/A-amyQ was transformed into the competent cells of Bacillus subtilis
WB600. The transformants were selected at $37^{\circ} \mathrm{C}$ on the LB agar plates containing $100 \mu \mathrm{g} / \mathrm{mL}$ Kanamycin and $1 \%$ soluble starch for $8 \mathrm{~h}$. The transformants with transparent rings around colonies were positive. The presence of alkaline $\alpha$-amylase gene in the transformants was confirmed by PCR. The colonies were grown in $25 \mathrm{~mL}$ of LB medium at $37^{\circ} \mathrm{C}$ for $36 \mathrm{~h}$ in conical flasks $(250 \mathrm{~mL})$.

\section{Optimization of recombinant alkaline $\alpha$-amylase production}

The effects of culture conditions (starch concentration, peptone concentration, soybean meal concentration, and temperature) on the recombinant production of alkaline $\alpha$-amylase in B. subtilis were examined. The starch of different concentrations $(0,0.6,1.2,1.8,2.4,3.0,3.6$, and $4.2 \%(\mathrm{w} / \mathrm{v}))$ on the production of alkaline $\alpha$-amylase was added into the culture medium to examine the effects of starch on alkaline $\alpha$-amylase production. The peptone of different concentrations $(0.45,0.95,1.45,1.95,2.45$, 


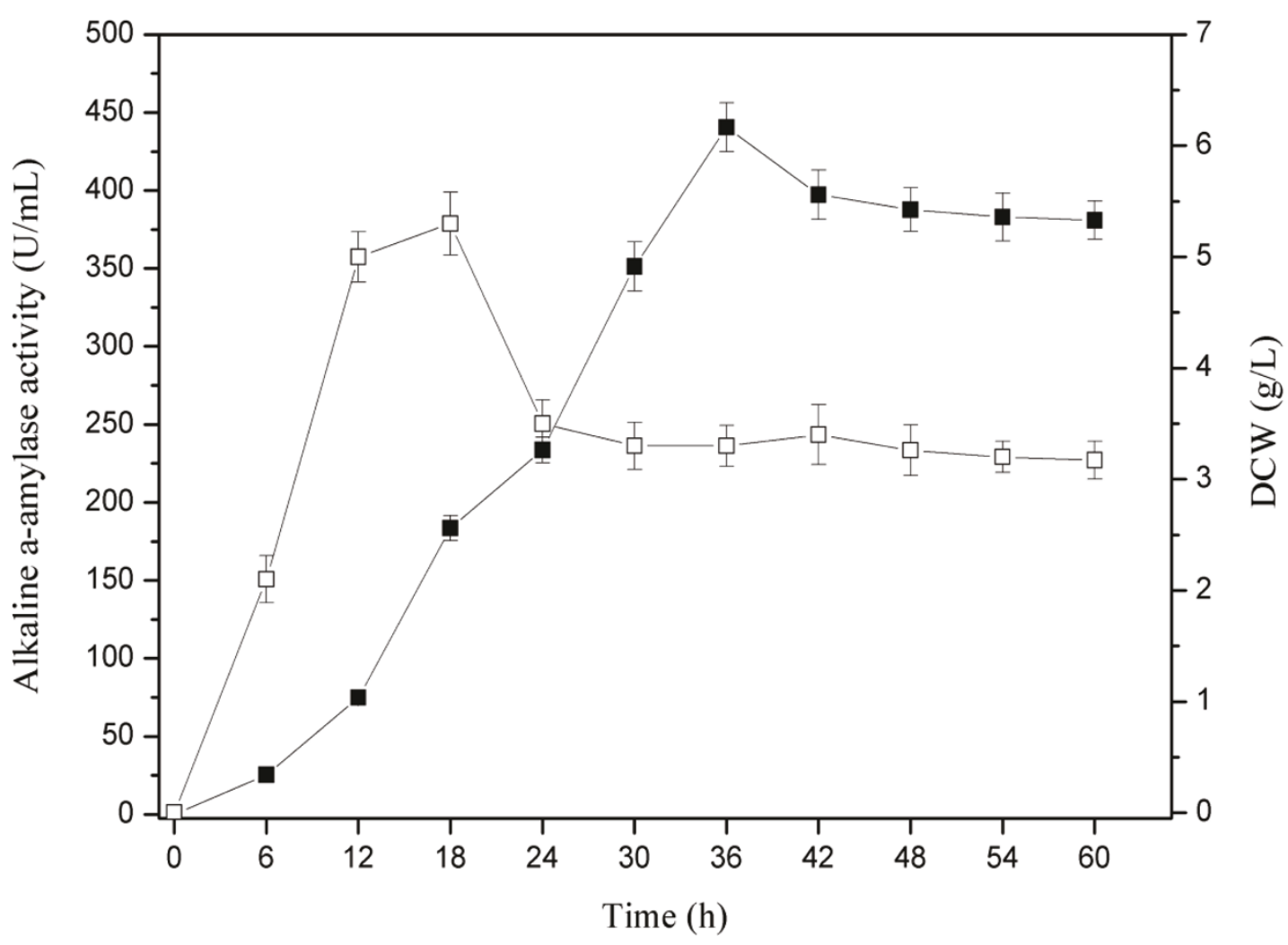

Figure 6 Time profiles for batch cultivation of recombinant B. subtilis in 3 L fermentor. Black square: the activity of alkaline $\alpha$-amylase (U/ $\mathrm{mL})$; White square: $D C W(\mathrm{~g} / \mathrm{L})$.

$2.95,3.45$, and $3.95 \%(\mathrm{w} / \mathrm{v}))$ was also added into the culture medium to examine the effects of peptone on alkaline $\alpha$-amylase production. Soybean meal of different concentrations $(0,0.3,0.8,1.3,1.8,2.3$, and $2.8 \%(\mathrm{w} / \mathrm{v}))$ was added into the culture medium to investigate the effects of soybean meal on the alkaline $\alpha$-amylase production. The effects of temperature $(25,28,31,34,37$, and $40^{\circ} \mathrm{C}$ ) on the production of alkaline $\alpha$-amylase were also investigated.

\section{Production of alkaline $\alpha$-amylase by recombinant $B$. subtilis in a 3-L fermentor}

The recombinant $B$. subtilis with the highest alkaline $\alpha$ amylase yield was used to scale up fermentation in a $3 \mathrm{~L}$ fermentor (BIOTRON, Korea). The medium was supplemented with $1.45 \%$ peptone, $0.6 \%$ soluble starch, $1.3 \%$ soybean meal, $1.0 \% \mathrm{NaCl}$ and $100 \mu \mathrm{g} / \mathrm{mL}$ Kanamycin. The fermentation was performed with a working volume of 1.6 $\mathrm{L}$ at $37^{\circ} \mathrm{C}$ for $60 \mathrm{~h}$. The stirring speed of fermentation was $600 \mathrm{rpm}$, and the volume of ventilation was $1 \mathrm{vvm}$.

\section{Enzyme assays}

Alkaline $\alpha$-amylase was determined by measuring the amount of reducing sugar released during enzymatic hydrolysis of $1 \%$ soluble starch in glycine/ $\mathrm{NaOH}$ buffer $\left(\mathrm{pH} \mathrm{10.0)}\right.$ at $55^{\circ} \mathrm{C}$ for $5 \mathrm{~min}$. A control without enzyme addition was used. The amount of reducing sugar was measured by a modified dinitrosalicylic acid method [36]. One unit of alkaline $\alpha$-amylase activity was defined as the amount of enzyme that released $1 \mu \mathrm{mol}$ of reducing sugar as glucose per min at the assay conditions.

\section{Purification and molecular weight determination of alkaline $\alpha$-amylase}

Solid ammonium sulfate was added to the supernatant to $70 \%$ saturation at $0^{\circ} \mathrm{C}$. The precipitate was collected and dissolved in glycine/ $\mathrm{NaOH}$ buffer $(\mathrm{pH} 9.0)$ and dialyzed overnight against the same buffer. After dialysis, the enzyme solution was filtered using water film. And then the enzyme solution was injected into AKTA purifier (GE Healthcare USA) through the anion exchange (Q-Sepharose HP). The subunit molecular weight of recombinant alkaline $\alpha$-amylase was determined by SDS-PAGE.

\section{Determination of kinetic parameters}

The reaction was performed in glycine/ $\mathrm{NaOH}$ buffer $(\mathrm{pH} 10.0)$ at $55^{\circ} \mathrm{C}$ for the determination of kinetic 
parameters. Assays were performed with active enzyme and soluble starch of different concentrations from 1 to $10 \mathrm{~g} / \mathrm{L}$. The Eadie-Hofstee plots were used to calculate kinetic parameters $K_{\mathrm{m}}$ and $V_{\max }$ according to the enzyme reactions [30].

\section{Effects of temperature and $\mathrm{pH}$ on activity}

To determine the optimal temperature, the enzyme was analyzed from 30 to $90^{\circ} \mathrm{C}$ in glycine/ $\mathrm{NaOH}$ buffer $(\mathrm{pH}$ 10.0 ). The thermal stability of alkaline $\alpha$-amylase was determined at the indicated temperatures in glycine/ $\mathrm{NaOH}$ buffer ( $\mathrm{pH}$ 10.0). To estimate the optimal $\mathrm{pH}$ for the alkaline $\alpha$-amylase, the purified protein was incubated in various buffers. The buffer used for determination of optimal $\mathrm{pH}$ was as follows: glycine/ $\mathrm{HCl}$ buffer for $\mathrm{pH}$ 3.0-6.0, glycine/ $\mathrm{NaOH}$ buffer for $\mathrm{pH}$ 6.0-11.0. The $\mathrm{pH}$ stability of alkaline $\alpha$-amylase was determined at $\mathrm{pH}$ ranging from 3.0 to 11.0 at $25^{\circ} \mathrm{C}$ for $24 \mathrm{~h}$. After incubation, the alkaline $\alpha$-amylase activity was measured at $\mathrm{pH} 10.0$ and $55^{\circ} \mathrm{C}$.

\section{Effects of metal ions on enzyme activity}

Alkaline $\alpha$-amylase was pre-incubated with $1 \mathrm{mM}$ and $10 \mathrm{mM} \mathrm{KCl}, \mathrm{NaCl}, \mathrm{CaCl}_{2}, \mathrm{MgCl}_{2}, \mathrm{FeCl}_{3}, \mathrm{FeCl}_{2}, \mathrm{CoCl}_{2}$, $\mathrm{ZnCl}_{2}, \mathrm{MnCl}_{2}$ and $\mathrm{CuCl}_{2}$, respectively. The relative activity was determined and compared with the activity obtained in glycine/ $\mathrm{NaOH}$ buffer ( $\mathrm{pH}$ 10.0) without the addition of any metal ions.

\section{Protein content assay}

The protein content of samples was measured by the Bradford method with BSA as a standard [37].

\begin{abstract}
Acknowledgements
This work was financially supported the Priority Academic Program Development of Jiangsu Higher Education Institutions, the National Natural Science Foundation of China (20836003), the Major State Basic Research Development Program of China (973 Program, 2012CB720806), and the National High Technology Research and Development Program of China (863 Program, 2011AA100905).
\end{abstract}

\section{Author details \\ 'Key Laboratory of Industrial Biotechnology, Ministry of Education, Jiangnan University, Wuxi 214122, China. ${ }^{2}$ School of Biotechnology, Jiangnan University, Wuxi 214122, China. ${ }^{3}$ State Key Laboratory of Food Science and Technology, Jiangnan University, Wuxi 214122, China.}

\section{Authors' contributions}

HQY carried out the cloning and expression of alkaline a-amylase, and drafted the manuscript. JHL carried out the fermentation. LL participated in the statistical analysis of data. GCD and JC critically revised and corrected the manuscript. All authors read and approved the final manuscript.

\section{Competing interests}

The authors declare that they have no competing interests.

Received: 2 August 2011 Accepted: 7 October 2011 Published: 7 October 2011
References

1. Wang N, Zhang Y, Wang Q, Liu J, Wang H, Xue Y, Ma Y: Gene cloning and characterization of a novel a-amylase from alkaliphilic Alkalimonas amylolytica. Biotechnol J 2006, 1:1258-65.

2. Malhotra R, Noorwez S, Satyanarayana T: Production and partial characterization of thermostable and calcium independent a-amylase of an extreme thermophile Bacillus thermooleovorans NP54. Lett Appl Microbiol 2000, 31:378-84.

3. Murakami S, Nishimoto H, Toyama Y, Shimamoto E, Takenaka S, Kaulpiboon J, Prousoontorn M, Limpaseni T, Pongsawasdi P, Aoki K: Purification and characterization of two alkaline, thermotolerant alphaamylases from Bacillus halodurans 38C-2-1 and expression of the cloned gene in Escherichia coli. Biosci Biotechnol Biochem 2007, 71:2393-401.

4. Hashim SO, Delgado O, Hatti-Kaul R, Mulaa FJ, Mattiasson B: Starch hydrolysing Bacillus halodurans isolates from a Kenyan soda lake. Biotechnol Lett 2004, 26:823-28.

5. Kim TU, Gu BG, Jeong JY, Byun SM, Shin YC: Purification and characterization of a maltotetraose-forming alkaline (alpha)-amylase from an alkalophilic Bacillus strain, GM8901. Appl Environ Microbiol 1995, 61:3105-122.

6. Schwermann B, Pfau K, Liliensiek B, Schleyer M, Fischer T, Bakker EP: Purification, properties and structural aspects of a thermoacidophilic aamylase from Alicyclobacillus Acidocaldarius ATCC 27009. Eur J Biochem 1994, 226:981-91.

7. Murakami S, Nagasaki K, Nishimoto H, Shigematu R, Umesaki J, Takenaka S, Kaulpiboon J, Prousoontorn M, Limpaseni T, Pongsawasdi P: Purification and characterization of five alkaline, thermotolerant, and maltotetraoseproducing [alpha]-amylases from Bacillus halodurans MS-2-5, and production of recombinant enzymes in Escherichia coli. Enzyme Microb Technol 2008, 43:321-28.

8. Burhan A, Nisa U, G khan C, mer C, Ashabil A, Osman G: Enzymatic properties of a novel thermostable, thermophilic, alkaline and chelator resistant amylase from an alkaliphilic Bacillus sp. isolate ANT-6. Process Biochem 2003, 38:1397-403.

9. Hagihara H, Igarashi K, Hayashi Y, Endo K, Ikawa-Kitayama K, Ozaki K, Kawai S, Ito S: Novel \{alpha\}-amylase that is highly resistant to chelating reagents and chemical oxidants from the alkaliphilic Bacillus isolate KSM-K38. Appl Environ Microbiol 2001, 67:1744-750.

10. Igarashi K, Hatada Y, Hagihara H, Saeki K, Takaiwa M, Uemura T, Ara K, Ozaki K, Kawai S, Kobayashi T: Enzymatic properties of a novel liquefying alpha-amylase from an alkaliphilic Bacillus isolate and entire nucleotide and amino acid sequences. Appl Environ Microbiol 1998, 64:3282-289.

11. Kuilderd H, Wu G: Applied technology-simultaneous desizing and scouring with enzymes-simultaneous fabric desizing and scouring, using alkaline alpha-amylase and an alkaline scouring enzyme, reduces water. AATCC Rev-Am Asoc Text Chem Color 2008, 8:33-6.

12. Chen DL, Tong X, Chen SW, Chen S, Wu D, Fang SG, Wu J, Chen J: Heterologous expression and biochemical characterization of aglucosidase from Aspergillus niger by Pichia pastroris. J Agric Food Chem 2010, 58:4819-824.

13. Saxena RK, Dutt K, Agarwal L, Nayyar P: A highly thermostable and alkaline amylase from a Bacillus sp. PN5. Bioresour Technol 2007 98:260-65.

14. Dastager GS, Li WJ, Agasar D, Sulochana MB, Tang SK, Tian XP, Zhi XY: Streptomyces gulbargensis sp. nov., isolated from soil in Karnataka, India. Antonie Van Leeuwenhoek 2007, 91:99-104.

15. Boyer E, Ingle M, Mercer G: Bacillus alcalophilus subsp. halodurans subsp. nov.: An alkaline-amylase-producing, alkalophilic organism. Int J Syst Bacteriol 1973, 23:238-42

16. Syed DG, Agasar D, Pandey A: Production and partial purification of aamylase from a novel isolate Streptomyces gulbargensis. J Ind Microbiol Biotechnol 2009, 36:189-94.

17. Medda S, Chandra AK: New strains of Bacillus licheniformis and Bacillus coagulans producing thermostable a-amylase active at alkaline $\mathrm{pH}$. J Appl Microbiol 2008, 48:47-58.

18. Hashim SO, Delgado OD, Martínez MA, Kaul RH, Mulaa FJ, Mattiasson B: Alkaline active maltohexaose-forming [alpha]-amylase from Bacillus halodurans LBK 34. Enzyme Microbial Technol 2005, 36:139-46.

19. Pancha I, Jain D, Shrivastav A, Mishra S, Shethia B, Mishra S, VP M, Jha B: A thermoactive [alpha]-amylase from a Bacillus sp. isolated from CSMCRI salt farm. Int J Biol Macromol 2010, 47:288-91. 
20. Ming YM, Wei ZW, Lin CY, Sheng GY: Research Development of a Bacillus subtilis expression system using the improved Pglv promoter. Microb Cell Fact 2010, 9:55.

21. Schallmey M, Singh A, Ward OP: Developments in the use of Bacillus species for industrial production. Can J Microbiol 2004, 50:1-17.

22. Kouwen TRHM, Nielsen AK, Denham EL, Dubois JYF, Dorenbos R, Rasmussen MD, Quax WJ, Freudl R, van Dijl JM: Contributions of the preand pro-regions of a Staphylococcus hyicus lipase to secretion of a heterologous protein by Bacillus subtilis. Appl Environ Microbiol 2010 76:659-69.

23. Harwood CR, Cranenburgh R: Bacillus protein secretion: an unfolding story. Trends Microbiol 2008, 16:73-9.

24. Tjalsma H, Antelmann H, Jongbloed JDH, Braun PG, Darmon E, Dorenbos R, Dubois JYF, Westers H, Zanen G, Quax WJ: Proteomics of protein secretion by Bacillus subtilis: separating the "secrets" of the secretome. Microb Mol Biol Rev 2004, 68:207-33.

25. Tjalsma H, Bolhuis A, Jongbloed JDH, Bron S, Van Dijl JM: Signal peptidedependent protein transport in Bacillus subtilis: a genome-based survey of the secretome. Microbiol Mol Biol Rev 2000, 64:515-47.

26. Braun P, Gerritset G, van Dijl JM, Quax WJ: Improving protein secretion by engineering components of the bacterial translocation machinery. Curr Opin Biotechnol 1999, 10:376-81.

27. Kobayashi K, Ehrlich SD, Albertini A, Amati G, Andersen K, Arnaud M, Asai K, Ashikaga S, Aymerich S, Bessieres P: Essential Bacillus subtilis genes. Proc Nat Acad Sci USA 2003, 100:4678-683.

28. Kunst F, Ogasawara N, Moszer I, Albertini A, Alloni G, Azevedo V, Bertero M, Bessieres $P$, Bolotin A, Borchert S: The complete genome sequence of the gram-positive bacterium Bacillus subtilis. Nature 1997, 390:249-56.

29. Chen J, Du GC, Liu L, Li JH, Yang HQ: A Bacillus alcalophilus JN21 that capable of producing alkaline a-amylase., Patent number: 2011101356049.

30. Fuhrmann GF, Völker B: Misuse of graphical analysis in nonlinear sugar transport kinetics by Eadie-Hofstee plots. BBA-Biomembr 1993, 1145:180-82

31. Oliveira A, Oliveira L, Andrade J: Partial characterization of amylases of two indigenous Central Amazonian rhizobia strains. Braz Arch Biol Technol 2010, 53:35-45.

32. Pandey A, Nigam P, Soccol C, Soccol V, Singh D, Mohan R: Advances in microbial amylases. Biotechnol Appl Biochem 2000, 31:135-52.

33. Gupta R, Gigras P, Mohapatra H, Goswami VK, Chauhan B: Microbial [alpha]-amylases: a biotechnological perspective. Process Biochem 2003, 38:1599-616.

34. Ramachandran S, Patel AK, Nampoothiri KM, Chandran S, Szakacs G, Soccol CR, Pandey A: Alpha amylase from a fungal culture grown on oil cakes and its properties. Braz Arch Biol Technol 2004, 47:309-17.

35. Chakraborty K, Bhattacharyya B, Sen S: Purification and characterization of a thermostable a-amylase from Bacillus stearothermophilus. Folia Microbiol 2000, 45:207-10.

36. Fuwa $\mathrm{H}$ : A new method for microdetermination of amylase activity by the use of amylose as the substrate. J Biochem 1954, 41:583-603.

37. Bradford MM: A rapid and sensitive method for the quantitation of microgram quantities of protein utilizing the principle of protein-dye binding. Anal Biochem 1976, 72:248-54.

doi:10.1186/1475-2859-10-77

Cite this article as: Yang et al:: Heterologous expression, biochemical characterization, and overproduction of alkaline $\alpha$-amylase from Bacillus alcalophilus in Bacillus subtilis. Microbial Cell Factories 2011 10:77.

\section{Submit your next manuscript to BioMed Central and take full advantage of:}

- Convenient online submission

- Thorough peer review

- No space constraints or color figure charges

- Immediate publication on acceptance

- Inclusion in PubMed, CAS, Scopus and Google Scholar

- Research which is freely available for redistribution

Submit your manuscript at www.biomedcentral.com/submit
Biomed Central 